\title{
Effects of 24-epibrassinolide on germination and growth of tomato seedlings under salt stress
}

\author{
Sebastião de Oliveira Maia Júnior', Jailma Ribeiro de Andrade ${ }^{1}$, Robson Felipe de Lima1, \\ Rafaela Félix Basílio Guimarães ${ }^{1}$, Allesson Ramos de Souza1, Ronaldo do Nascimento ${ }^{1}$ \\ ${ }^{1}$ Unidade Acadêmica de Engenharia Agrícola, Universidade Federal de Campina Grande, Campina Grande, Paraíba, Brasil. E-mail: \\ juniormaiagrari@hotmail.com, jailma_asf@hotmail.com, robson_felipe88@hotmail.com, rafaellafelix_@hotmail.com, \\ allesson13@outlook.com, ronaldon453@gmail.com
}

Received: 20/04/2020; Accepted: 03/11/2020.

\begin{abstract}
Salinity is one of the environmental stresses that most affects plants' vital processes, especially germination. Brassinosteroids, including 24-epibrassinolide (EBL), have multiple actions in essential processes in plants. Thus, this research's objective was to evaluate the effects of EBL on tomato seeds' physiological conditioning on germination, growth, and production of dry seedling mass under salinity conditions. The experiment was carried out in a $2 \times 5$ factorial scheme, as follows: two concentrations of EBL $\left(0\right.$ and $\left.10^{-6} \mathrm{M}\right)$ and five levels of salinity $(0.5$ control; $1.5 ; 3.0 ; 4.5$ and $6.0 \mathrm{dS} \mathrm{m}^{-1}$ ), consisting of ten treatments, with four replications of 50 seeds. In isolation, the salt stress reduced the percentage of germination and germination speed index from four to 14 days, besides all the plants' growth traits. In turn, the EBL increased the percentage of germination, germination speed index, seedling length, and radicle dry matter. The application of $10^{-6} \mathrm{M}$ of EBL in seed immersion no effect on the seed germination of IPA 6 tomato cultivar under salt stress but increases the root length and the dry matter of the seedlings.
\end{abstract}

Keywords: Lycopersicon esculentum, $\mathrm{NaCl}$, 24-epibrassinolide, Tolerance.

\section{Efeitos do 24-epibrassinolídeo na germinação e no crescimento de plântulas de tomate sob estresse salino}

\section{RESUMO}

A salinidade é um dos estresses ambientais que mais afeta os processos vitais das plantas, sobretudo a germinação. Os brassinosteroides, incluindo o 24-epibrassinolídeo (EBL), têm múltiplas ações em processos essenciais nas plantas. Dessa forma, o objetivo desta pesquisa foi avaliar os efeitos do EBL no condicionamento fisiológico de sementes de tomate sobre a germinação, o crescimento e a produção de massa seca de plântulas em condições de salinidade. $\mathrm{O}$ experimento foi realizado em esquema fatorial $2 \times 5$, sendo: duas concentrações de EBL $\left(0\right.$ e $\left.10^{-6} \mathrm{M}\right)$ e cinco níveis de salinidade ( 0,5 controle; 1,$5 ; 3,0 ; 4,5$ e $\left.6 \mathrm{dS} \mathrm{m}^{-1}\right)$, consistindo em dez tratamentos, com quatro repetições de 50 sementes. De forma isolada, o estresse salino reduziu a porcentagem e o índice de velocidade de germinação dos quatro aos 14 dias, além de todas as características de crescimento das plântulas. Por sua vez, o EBL aumentou a porcentagem e o índice de velocidade de germinação, o comprimento da plântula e o peso seco da radícula. A aplicação de $10^{-6} \mathrm{M}$ de EBL na imersão das sementes não influencia na germinação de sementes do tomate cultivar IPA 6 sob estresse salino, mas aumenta o comprimento da radícula e o peso seco das plântulas.

Palavras-chave: Lycopersicon esculentum, $\mathrm{NaCl}$, 24-epibrassinolídeo, Tolerância. 


\section{Introduction}

Plants are affected by several types of stress in nature, among which salinity is one of those that cause more damage to plants (Giannakoula and Ilias, 2013; Poór et al., 2019). This type of environmental stress prevails, especially in arid and semi-arid regions characterized by irregular spatial and temporal rainfall distribution, and irrigation one of the main technologies used to ensure agricultural production (Souza et al., 2016). However, most of the time, the water is not of good quality, as it contains a high concentration of salts, which causes severe restrictions in the metabolic processes of plants, such as seed germination (Abbas et al., 2014; Zhang et al., 2016), mainly in species such as tomato which is considered moderately sensitive to salinity (Ayers and Westcot, 1999).

The effects of salinity on seed germination in many species can occur by reducing the germination percentage and prolonging the time needed to complete germination (Munns and Tester, 2008; Campos et al., 2007). Under salinity conditions, it was observed in IPA 6 tomato cultivar that water salinity by $5.0 \mathrm{dS} \mathrm{m} \mathrm{m}^{-1} \mathrm{did}$ not affect the germination rate but reduced the speed of emergence with the increase in saline stress (Campos et al., 2007). In another study also with tomato, the percent seed germination decreased with increasing salt concentration, $68.2 \%(0 \mathrm{mM})$ to $5.9 \%(150 \mathrm{mM})$ in different varieties (Chakma et al., 2019). In pepper, the seed germination also gradually decreased as the $\mathrm{NaCl}$ concentration increased (Demir and Mavi, 2008).

However, techniques or measures that search to mitigate the effects of salinity in plants have been used, such as the physiological conditioning of seeds with brassinosteroids, which have played an important role in tolerating the stress of salinity in several cultures, including the vegetables (Houimli et al., 2010; Tanveera et al., 2018).

Several studies prove the positive effects of brassinosteroids (24-epibrassinolide analog - EBL) in different plant species under salinity. This phytohormone alleviated the adverse effects of salt on rice, maintaining the physiological quality of the seeds and the growth characteristics of the seedlings in the cultivar sensitive to salinity (Larré et al., 2011), and barley improving radicle and shoot length, as well as fresh seedling matter (Azhar et al., 2017). EBL's importance in inducing tolerance to salt stress in several plant species, and the scarcity of studies involving physiological conditioning in tomato seeds, the present study is of special interest to improve crop production under salinity conditions. This research hypothesizes that the EBL would enhance the tolerance to salt in tomato seedlings through seed pre-treatment.

Thus, this research's objective was to evaluate the effects of EBL on the physiological conditioning of tomato seeds on germination, growth, and seedling dry matter production under salinity conditions.

\section{Material and Methods}

The research was carried out at the Plant Physiology Laboratory belonging to the Agricultural Engineering Academic Unit of the Federal University of Campina Grande, Campina Grande, PB, Brazil. Seeds of IPA 6 tomato cultivar were soaked (pre-treated) in $10^{-6} \mathrm{M} 24-$ epibrassinolide solution (EBL) or deionized water (control) for $24 \mathrm{~h}$. Subsequently, the seeds were placed to germinate on germitest paper $^{\circledR}$, moistened with saline solutions at a ratio of 2.5 times the dry substrate (Brasil, 2009) and, maintained in a BOD (biochemical oxygen demand) type germination chamber at $25^{\circ} \mathrm{C} \pm 1$ (Abdel et al., 2016), and photoperiod of $12 \mathrm{~h}$. In the simulation of salt stress, sodium chloride $(\mathrm{NaCl})$ was used in the concentrations of 0.5 (control); $1.5 ; 3.0 ; 4.5$ and $6.0 \mathrm{dS}$ $\mathrm{m}^{-1}$, whose values were verified with the aid of a bench conductivimeter. The electrical conductivity of the sodium chloride solutions was obtained, according to Richards (1954).

The experimental design adopted was completely randomized in a $2 \times 5$ factorial scheme, with two concentrations of brassinosteroids ( 0 and $10^{-6} \mathrm{M}$ EBL; 24-epibrassinolide) and five salinity concentrations ( 0.5 ; $1.5 ; 3.0 ; 4.5$ and $6.0 \mathrm{dS} \mathrm{m}^{-1}$ ), consisting of ten treatments, with four replicates of 50 seeds. The 24-epibrassinolide analog P.A. (SIGMA - ALDRICH®) has a molecular weight of $480.68 \mathrm{~g} \mathrm{~L}^{-1}$ and purity $\geqq$ of $85 \%$. The stock solution was prepared using $2 \mathrm{mg}$ in $100 \mathrm{~mL}$ of deionized water, and from this solution, a $10^{-6} \mathrm{M}$ concentration was prepared.

The seeds were considered germinated when the radicle was greater than $2.0 \mathrm{~mm}$, recorded from four to 14 days after the test's start, adapted from Brasil (2009). At that time, the percentage and index of germination speed were evaluated. The germination percentage, as $G$ $=\mathrm{n} / \mathrm{N} \times 100$, where $\mathrm{n}=$ number of seeds germinated on count day and $\mathrm{N}=$ total number of seeds sown; and the germination speed index: GSI $=\mathrm{G} 1 / \mathrm{N} 1+\mathrm{G} 2 / \mathrm{N} 2+$ $\mathrm{Gn} / \mathrm{Nn}$, where $\mathrm{G}=$ the number of seedlings germinated in each count and $\mathrm{N}=$ the number of sowing days, according to Maguire (1962).

The length of the shoot and the radicle were measured in 10 normal seedlings obtained at random after the total germination count (at 14 days) using a ruler, with results expressed in $\mathrm{cm}$.

The same seedlings used to measure the length were also used to determine the dry matter partition, separated into radicle and shoot, and placed to dry in a forced air circulation oven at $65^{\circ} \mathrm{C}$ for 48 hours then weighed. The results were expressed in $\mathrm{mg}$ per seedling. 
The data were subjected to analysis of variance. When significant, the salinity concentrations were subjected to polynomial regression, and the treatments with brassinosteroids were compared by the $\mathrm{F}$ test at 1 and $5 \%$ probability.

\section{Results and Discussion}

The germination speed index (GSI) and the germination percentage $(G)$ of IPA 6 tomato cultivar varied, in isolation, between salinity levels and the application of EBL from four to 14 days after sowing (Table 1).

Throughout the evaluation period, GSI and G reduced with the increase in salinity (Table 2). At the beginning of germination, at four days, the GSI decreased by $70.1 \%$ with the increase in the salinity of 0.5 to $6.0 \mathrm{dS} \mathrm{m}^{-1}$, ending at $38.5 \%$ in that same salinity interval (14 days).

The $\mathrm{G}$ either decreased with increasing salinity, $70.2 \%$ at four days, and $39 \%$ at 14 days (Table 2). Both GSI and G were favored by the use of EBL throughout the germination period. The EBL promoted GSI 11 and $19.5 \%$ greater at four and 14 days, respectively, similar to the increase in $\mathrm{G}$ that was 11.1 e $19.7 \%$, respectively, to four and 14 days after germination (Table 2).

These reductions may be due to the excessive deposition of $\mathrm{Na}^{+}$and $\mathrm{Cl}^{-}$ions in the seed tissues that compromise germinative metabolism, affecting the mobilization of mineral and organic reserves beyond the return of breathing (Shahid et al., 2011). These results were consistent with those of Campos et al. (2007) and Chakma et al. (2019) in tomato, Larré et al. (2011) in rice, and Azhar et al. (2017) in barley, that they said salinity affect the germination of seeds beyond the seedling growth, due to difficulty in the absorption of water. However, the results of the last authors differed from those of this study regarding the attenuation of saline stress by EBL on germination since the soaking of rice seeds for two hours at $0.01 ; 0.1$ and $1 \mu \mathrm{M}$ EBL mitigated the negative effect of salinity on the percentage of germination and germination speed index, especially in the sensitive cultivar, while barley seeds germinated in saline solutions with $0.1 ; 0.25$ and $0.5 \mathrm{mg} \mathrm{L}^{-1}$ of EBL improved the germination percentage, depending on the concentration and intensity of salt stress (Azhar et al., 2017). Thus, it can be suggested that the improvement of tomato germination by EBL under salinity is linked to concentration and the cultivar used. However, EBL has increased the percentage of germination and the length of seedlings, independent of salt stress.

The salt stress caused a significant effect on all the growth characteristics of seedlings and the same dry matter. In contrast, the EBL affected the shoot length, total seedling length, shoot dry matter, radicle dry matter, and total seedling dry matter (Table 3 ). The interaction between salinity and EBL affected only radicle length, total seedling length, and seedling dry matter.

The increase in salt stress linearly reduced $9.4 \%$ the SL between 0.5 and $6.0 \mathrm{dS} \mathrm{m}^{-1}$, while the EBL increased by $4.3 \%$ compared to treatment without phytohormone (Figure 1A and B). Salinity also reduced RL and TSL, more pronounced in the treatment without EBL with reductions of 125.0 and $63.9 \%$, respectively. In comparison, EBL's use reduced the effects of salt with reductions to 85.5 and $50.2 \%$, respectively (Figure 1C and D).

Campos et al. (2007) also observed in tomato that the seedling length was affected by the salinity of the water, with a reduction of 4.96 and $8.96 \%$ for each unit increase of electrical conductivity of water (ECw) over $1 \mathrm{dS} \mathrm{m}^{-1}$ at 7 and 14 days after sowing, respectively. Likewise, the shoot length of the shoot of rice seedlings was significantly reduced by salinity $(100 \mathrm{mM} \mathrm{NaCl})$ compared to the control treatment. The cultivar is sensible with the larger decrease owing to salinity. However, it showed good recovery when the seeds were treated with 24-epibrassinolide, similar to what occurred in this study with the conditioning of tomato seeds with EBL.

The shoot dry matter had a quadratic behavior with the increase of saline levels, reaching a maximum of 12.4 and $16.2 \mathrm{mg}$ in the estimated salinities of 4.1 and $4.4 \mathrm{dS}$ m-1 in treatments with and without EBL, respectively (Figure 2A). The RDM decreased linearly with an increase in salt stress of $17.3 \%$ between 0.5 and $6.0 \mathrm{dS}$ $\mathrm{m}^{-1}$ (Figure 2B), while the EBL increased by $7.6 \%$ compared to treatment without phytohormone (Figure 2C). As well as the shoot dry matter, the total dry matter of seedlings had a quadratic behavior with the increase of salt stress, reaching a maximum of 19.9 and $20.0 \mathrm{mg}$ in the estimated salinities of 3.4 and $4.2 \mathrm{dS} \mathrm{m}^{-1}$ in treatments with and without EBL, respectively (Figure 2D).

Regarding the increase in shoot dry matter with salt stress, Demir and Mavi (2008) found similar results in pepper seedlings under different osmotic potentials induced by $\mathrm{NaCl}$. The authors attributed the highest gains in the biomass with the stress imposition to increase cell division and synthesis of materials, such as sugars. Larré et al. (2011) also observed in rice that the dry matter of seedlings increased with salinity in seedlings treated with 0.1 and $1 \mu \mathrm{M}$ of EBL.

The benefits of EBL in pre-treatment of seeds in the attenuation of salt stress, especially in the radicle length and seedling dry matter of tomato, probably occurred because this phytohormone is involved in modifying the structure and integrity of membranes under stress conditions, promoting the activity of the antioxidant defense system (Larré et al., 2011; Shahid et al., 2011). This can be seen in rice seedlings in which the pretreatment of seeds with $10^{-11}, 10^{-9}$, and $10^{-7} \mathrm{M}$ of EBL 
showed an improvement in the activity of antioxidant enzymes, in the levels of protein and proline, beyond seedlings growth, stabilizing the integrity membranes by reducing lipid peroxidation during saline stress (Sharma et al., 2013).
Additional research is recommended to study EBL use with different concentrations and at different stages of cultivation. Thus, it will be possible to obtain evidence that reinforces this research results and may point to the use of EBL as a mitigating of salt stress in tomato.

Table 1. Summary of the analysis of variance for the germination speed index and germination percentage, from four to 14 days after IPA 6 tomato cultivar sowing under salinity levels and epibrassinolide application. Campina Grande-PB, Brazil, 2019.

\begin{tabular}{|c|c|c|c|c|c|c|c|c|c|c|c|c|}
\hline \multirow{3}{*}{ SV } & \multirow[t]{3}{*}{ DF } & \multicolumn{11}{|c|}{ F-test } \\
\hline & & \multicolumn{11}{|c|}{ Germination speed index - days } \\
\hline & & 4 & 5 & 6 & 7 & 8 & 9 & 10 & 11 & 12 & 13 & 14 \\
\hline Salt & 4 & $* *$ & ** & $* *$ & $* *$ & *** & ** & $* *$ & $* *$ & $* *$ & $* *$ & $* *$ \\
\hline EBL & 1 & $* *$ & $* *$ & $* *$ & $* *$ & $* *$ & $* *$ & $* *$ & $* *$ & $* *$ & $* *$ & $* *$ \\
\hline S*EBL & 4 & ns & ns & ns & ns & ns & ns & ns & ns & ns & ns & ns \\
\hline \multirow[t]{2}{*}{ Error } & 27 & -- & -- & -- & -- & -- & -- & -- & -- & -- & -- & -- \\
\hline & & \multicolumn{11}{|c|}{ Germination percentage $(\%)$ - days } \\
\hline Salt & 4 & $* *$ & $* *$ & $* *$ & $* *$ & $* *$ & ** & $* *$ & $* *$ & $* *$ & ** & $* *$ \\
\hline EBL & 1 & $* *$ & $* *$ & $* *$ & $* *$ & $* *$ & $* *$ & $* *$ & $* *$ & $* *$ & $* *$ & $* *$ \\
\hline $\mathrm{S}^{*} \mathrm{EBL}$ & 4 & ns & ns & ns & ns & ns & ns & ns & ns & ns & ns & ns \\
\hline Error & 27 & -- & -- & -- & -- & -- & -- & -- & -- & -- & -- & -- \\
\hline
\end{tabular}

$\mathrm{SV}=$ Sources of variation; $\mathrm{DF}=$ degrees of freedom; $* *$ and $*=$ significant at $1 \%$ and $5 \%$ probability by F-test, respectively; ns $=$ not significant.

Table 2. Averages of germination speed index and germination percentage, from four to 14 days after IPA 6 tomato cultivar sowing under salinity levels and epibrassinolide application. Campina Grande-PB, Brazil, 2019.

\begin{tabular}{|c|c|c|c|c|c|c|c|c|c|c|c|}
\hline \multirow[t]{2}{*}{ Salinity level $\left(\mathrm{dS} \mathrm{m}^{-1}\right)$} & \multicolumn{11}{|c|}{ Germination speed index - (days) } \\
\hline & 4 & 5 & 6 & 7 & 8 & 9 & 10 & 11 & 12 & 13 & 14 \\
\hline 0.5 & 6.21 & 5.85 & 5.31 & 4.66 & 4.15 & 3.69 & 3.35 & 3.07 & 2.82 & 2.60 & 2.41 \\
\hline 1.5 & 5.56 & 5.27 & 4.81 & 4.23 & 3.78 & 3.43 & 3.08 & 2.80 & 2.57 & 2.37 & 2.20 \\
\hline 3.0 & 4.68 & 4.42 & 4.04 & 3.55 & 3.25 & 2.95 & 2.67 & 2.43 & 2.25 & 2.07 & 1.92 \\
\hline 4.5 & 4.15 & 4.25 & 3.89 & 3.51 & 3.14 & 2.83 & 2.56 & 2.32 & 2.13 & 1.97 & 1.83 \\
\hline 6.0 & 3.65 & 3.95 & 3.62 & 3.23 & 2.90 & 2.62 & 2.40 & 2.21 & 2.03 & 1.87 & 1.74 \\
\hline \multicolumn{12}{|l|}{$\overline{\mathrm{EBL}}$} \\
\hline with & 5.11 & 5.03 & 4.68 & 4.15 & 3.75 & 3.40 & 3.07 & 2.80 & 2.57 & 2.37 & 2.20 \\
\hline without & 4.60 & 4.47 & 3.99 & 3.52 & 3.13 & 2.81 & 2.55 & 2.34 & 2.15 & 1.98 & 1.84 \\
\hline Salinity level $\left(\mathrm{dS} \mathrm{m}^{-1}\right)$ & \multicolumn{11}{|c|}{ Germination percentage $(\%)$ - days } \\
\hline & 4 & 5 & 6 & 7 & 8 & 9 & 10 & 11 & 12 & 13 & 14 \\
\hline 0.5 & 49.7 & 58.5 & 63.7 & 65.2 & 66.5 & 66.5 & 67.0 & 67.7 & 67.7 & 67.7 & 67.7 \\
\hline 1.5 & 44.5 & 52.7 & 57.7 & 59.2 & 60.5 & 61.7 & 61.7 & 61.7 & 61.7 & 61.7 & 61.7 \\
\hline 3.0 & 37.5 & 44.2 & 48.5 & 49.7 & 52.0 & 53.2 & 53.5 & 53.5 & 54.0 & 54.0 & 54.0 \\
\hline 4.5 & 33.2 & 42.5 & 46.7 & 49.2 & 50.2 & 51.0 & 51.2 & 51.2 & 51.2 & 51.2 & 51.2 \\
\hline 6.0 & 29.2 & 39.5 & 43.5 & 45.2 & 46.5 & 47.2 & 48.0 & 48.7 & 48.7 & 48.7 & 48.7 \\
\hline \multicolumn{12}{|l|}{$\overline{\mathrm{EBL}}$} \\
\hline with & 40.9 & 50.3 & 58.2 & 60.1 & 61.3 & 61.5 & 61.6 & 61.6 & 61.8 & 61.8 & 61.8 \\
\hline without & 36.8 & 44.7 & 47.9 & 49.3 & 50.2 & 50.6 & 51.1 & 51.6 & 51.6 & 51.6 & 51.6 \\
\hline
\end{tabular}

Table 3. Summary of analysis of variance for shoot length (SL), radicle length (RL), total seedling length (TSL), shoot dry matter (SDM), radicle dry matter (RDM), and total seedling dry matter (TSM) of IPA 6 tomato cultivar under salinity levels and epibrassinolide application. Campina Grande-PB, Brazil, 2019.

\begin{tabular}{cccccccc}
\hline SV & DF & \multicolumn{3}{c}{ F-test } & \multicolumn{1}{c}{} \\
\cline { 3 - 8 } & & SL & RL & TSL & SDM & RDM & TSM \\
\hline Salt & 4 & $* *$ & $* *$ & $* *$ & $* *$ & $* *$ & $* *$ \\
EBL & 1 & $* *$ & ns & $* *$ & $* *$ & $* *$ & $* *$ \\
S*EBL & 4 & Ns & $* *$ & $* *$ & $* *$ & ns & $*$ \\
Error & 27 & -- & -- & -- & -- & -- & -- \\
\hline
\end{tabular}

$\mathrm{SV}=$ Sources of variation; $\mathrm{DF}=$ degrees of freedom; $* *$ and $*=$ significant at $1 \%$ and $5 \%$ probability by F-test, respectively; ns $=$ no significant. 

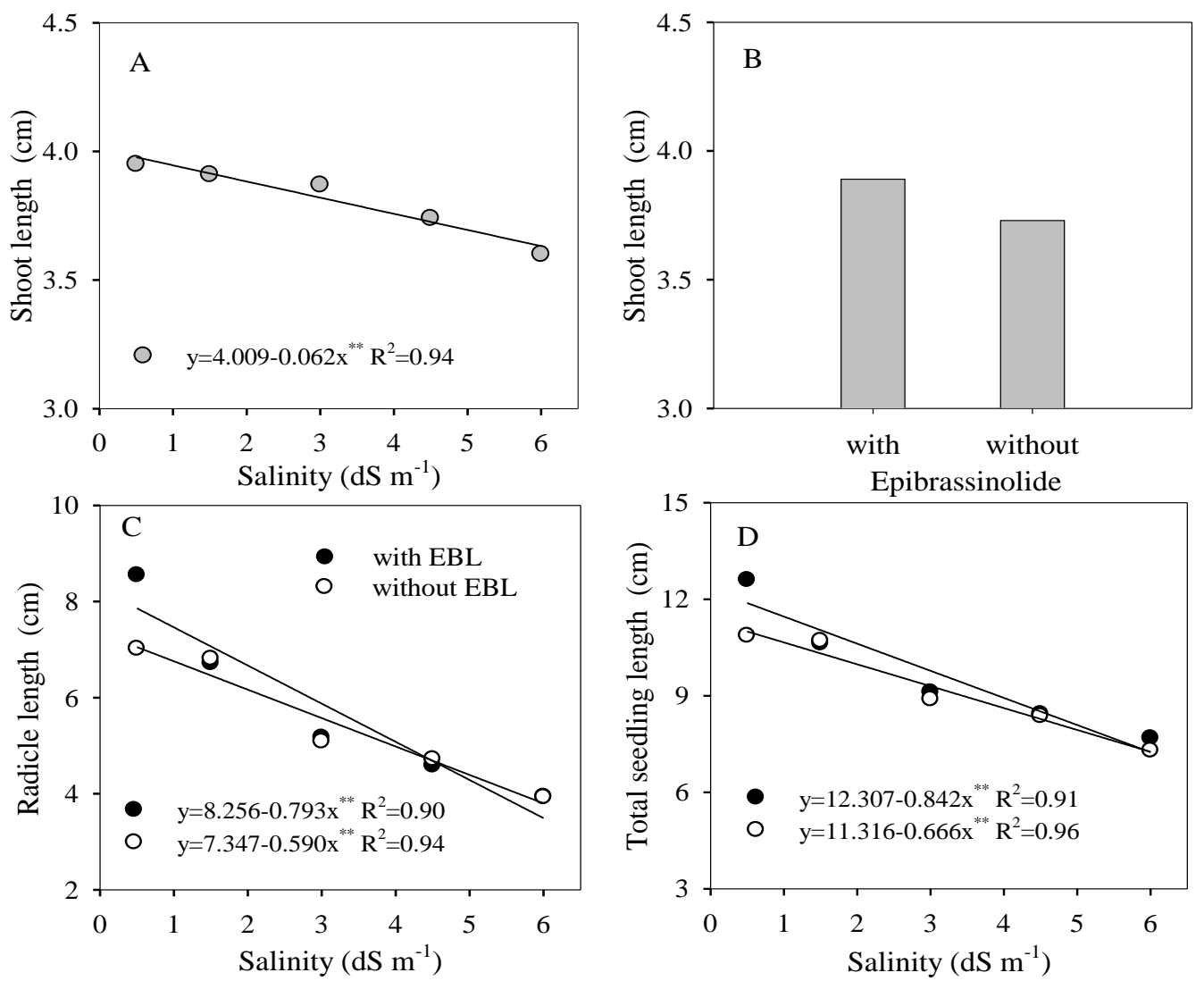

Figure 1. Shoot length - SL (A and B), radicle length - RL (C), and total seedling length - TSL (D) of IPA 6 tomato cultivar under salinity levels and epibrassinolide application. Campina Grande-PB, Brazil, 2019.
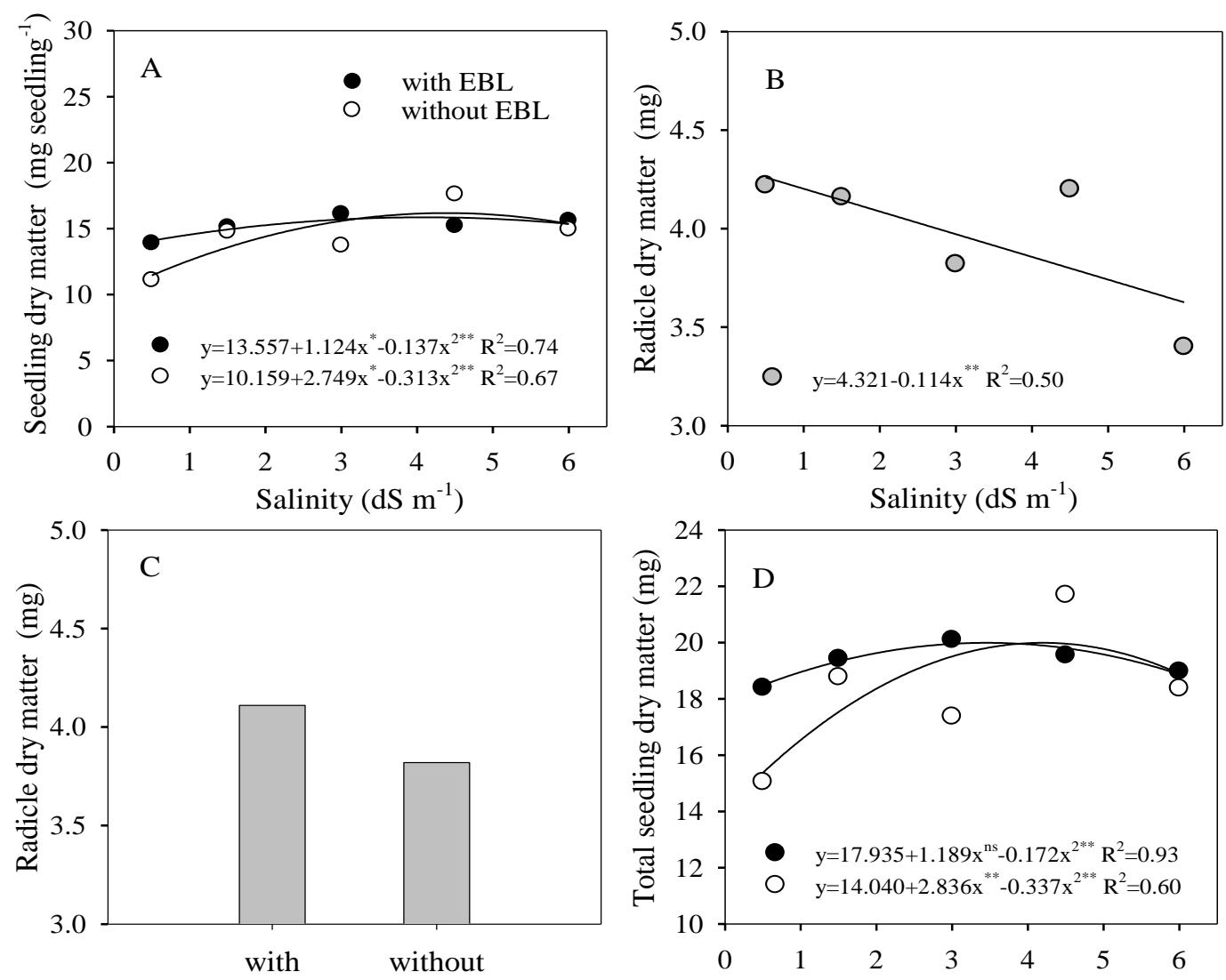

Epibrassinolide

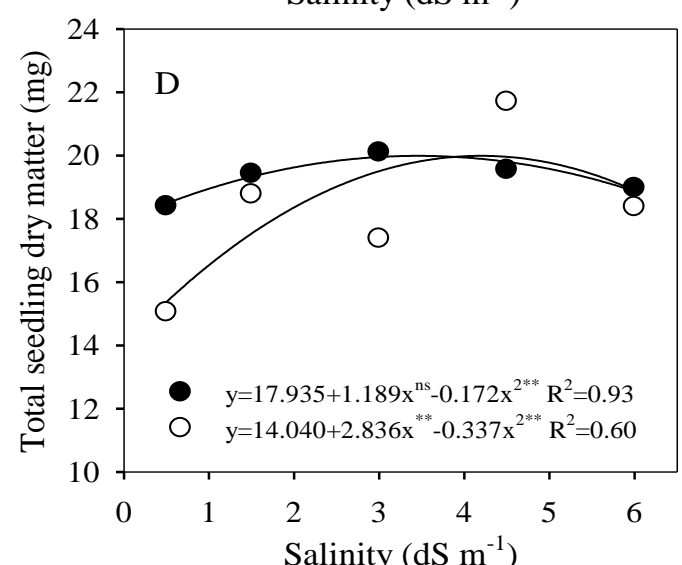

Figure 2. Shoot dry matter - SDM (A), radicle dry matter - RDM (B and C), and total seedling dry matter - TSM (D) of IPA 6 tomato cultivar under salinity levels and epibrassinolide application. Campina Grande-PB, Brazil, 2019. 


\section{Conclusions}

The application of $10^{-6} \mathrm{M}$ of EBL in the soaking of the seeds no affects the germination of IPA 6 tomato cultivar seeds under salt stress. Still, it increases radicle length and seedling dry matter.

\section{Authors' Contribution}

Sebastião de Oliveira Maia Júnior, Jailma Ribeiro de Andrade, Robson Felipe de Lima, Rafaela Félix Basílio Guimarães and Allesson Ramos de Souza conducted the experiment performing all stages of the assessments measured; Sebastião de Oliveira Maia Júnior designed the experiment, interpreted the data, discussed the analyses, and wrote the manuscript under Ronaldo do Nascimento supervision.

\section{Acknowledgments}

To Conselho Nacional de Desenvolvimento Científico e Tecnológico (CNPq) (Grant PDJPostdoctoral Junior 153397/2018-7 to first author).

\section{Bibliographic References}

Abbas, T., Pervez, M.A., Ayyub, C.M., Shaheen, M.R., Tahseen, S., Shahid, M.A., Manan, A. 2014. Evaluation of different okra genotypes for salt tolerance. International Journal of Plant, Animal and Environmental Sciences, 4(3), 23-30.

Abdel, C.G., Asaad, S.S., Mohammad, D.S. 2016. Minimum, optimum, and maximum temperatures required for germination of onion, radish, tomato and pepper. International Journal of Farming and Allied Sciences, 5(1), 26-45.

Ayers, R.S., Westcot, D.W. 1999. A qualidade de água na agricultura. Campina Grande, Universidade Federal da Paraíba, p. 1-53 (FAO Irrigation Drainage Daper, 29).

Azhar, N., Su, N., Shabala, L., Sergey, S.H. 2017. Exogenously Applied 24-Epibrassinolide (EBL) Ameliorates Detrimental Effects of Salinity by Reducing $\mathrm{K}^{+}$Efflux via DepolarizationActivated $\mathrm{K}^{+}$Channels. Plant Cell Physiology, 58(4), 802-810. DOI: https://doi.org/10.1093/pcp/pcx026.

Brasil. 2009. Ministério da Agricultura, Pecuária e Abastecimento. Regras para análise de sementes. Ministério da Agricultura, Pecuária e Abastecimento. Secretaria de Defesa Agropecuária. Brasília, Mapa/ACS, 399 p.

Campos, C.A.B., Fernandes, P.D., Gheyi, H.R., Blanco, F.F. 2007. Production of tomato seedlings under saline irrigation. Revista Caatinga, 20(2), 32-38.

Chakma, P., Hossain, M.M., Rabbani, M.G. 2019. Effects of salinity stress on seed germination and seedling growth of tomato. Journal of Bangladesh Agricultural University, 17(4), 490-499.

DOI: https://www.banglajol.info/index.php/JBAU/article/view/44617.
Demir, I., Mavi, K. 2008. Effect of salt and osmotic stresses on the germination of pepper seeds of different maturation stages. Brazilian Archives of Biology and Technology, 51(5), 897-902. DOI: https://doi.org/10.1590/S1516-89132008000500004.

Giannakoula, A.E., Ilias, I.F. 2013. The effect of water stress and salinity on growth and physiology of tomato (Lycopersicon esculentum Mill.). Archives Biology Science, 65(2), 611-620. DOI: https://doi.org/10.2298/ABS1302611G

Houimli, S.I.M., Denden, M., Mouhandes, B.D. 2010. Effects of 24-epibrassinolide on growth, chlorophyll, electrolyte leakage and proline by pepper plants under $\mathrm{NaCl}$ stress. EurAsia Journal BioScience, 4(1), 96-104. DOI: https://doi.org/10.5053/ejobios.2010.4.0.12.

Larré, C.F., Moraes, D.M., Lopes, N.F. 2011. Qualidade fisiológica de sementes de arroz tratadas com solução salina e 24-epibrassinolídeo. Revista Brasileira de Sementes, 33(1), 8694. DOI: https://doi.org/10.1590/S0101-31222011000100010.

Maguire, J.D. 1962. Speed of germination-aid in selection and evaluation of seedling emergence and vigour. Crop Science, 2(1), 176-177.

Munns, R., Tester, M. 2008. Mechanism of salinity tolerance. Annual Review of Plant Biology, 59(6), 651-681. DOI: https://doi.org/10.1146/annurev.arplant.59.032607.092911.

Poór, P., Borbély, P., Czékus, Z., Takács, Z., Ördög, A., Popović, B., Tari, I. 2019. Comparison of changes in water status and photosynthetic parameters in wild type and abscisic acid-deficient sitiens mutant of tomato (Solanum lycopersicum cv. Rheinlands Ruhm) exposed to sublethal and lethal salt stress. Journal of Plant Physiology, 232, 130-140. DOI: https://doi.org/10.1016/j.jplph.2018.11.015.

Richards, L.A. 1954. Diagnóstico y rehabilitacion de suelos salinos y sádicos. México: Departamento de Agricultura de los Estados Unidos de América, 172 p. (Manual de agricultura, 60).

Shahid, M.A., Pervez, M.A., Balal, R.M., Mattson, N.S., Rashid, A., Ahmad, R., C. Ayyub, M., Abbas, T. 2011. Brassinosteroid (24-Epibrassinolide) enhances growth and alleviates the deleterious effects induced by salt stress in pea ('Pisum sativum' L.). Australian Journal of Crop Science, 5(5), 500-510.

Sharma, I., Ching, E., Saini, S., Bhardwaj, R., Pati, P.K. 2013. Exogenous application of brassinosteroid offers tolerance to salinity by altering stress responses in rice variety Pusa Basmati-1. Plant Physiology and Biochemistry, 69, 17-26. DOI: https://doi.org/10.1016/j.plaphy.2013.04.013.

Souza, L.P., Nobre, R.G., Silva, E.M., Lima, G.S., Pinheiro, F.W.A., Almeida, L.L.S. 2016. Formation of 'Crioula' guava rootstock under saline water irrigation and nitrogen doses. Revista Brasileira de Engenharia Agrícola e Ambiental, 20(8), 739-745. DOI: $\quad$ https://doi.org/10.1590/18071929/agriambi.v20n8p739-745.

Tanveera, M., Shahzada, B., Sharmac, A., Bijub, S., Bhardwajc, R. 2018. 24-Epibrassinolide; an active brassinolide and its role in salt stress tolerance in plants: A review. Plant Physiology and Biochemistry, $130, \quad 69-79 . \quad$ DOI: https://doi.org/10.1016/j.plaphy.2018.06.035. 
Zhang, P., Senge, M., Dai, Y. 2016. Effects of salinity stress on growth, yield, fruit quality and water use efficiency of tomato under hydroponics system. Reviews in Agricultural Science, 4, 46-55. DOI: https://doi.org/10.1080/00103624.2016.1269803. 